\title{
Immunochemical Identification of the Major Cell Surface Agglutinogen of Acinetobacter calcoaceticus RAG-92
}

\author{
By EDWARD A. BAYER, ${ }^{*}+$ EHUD SKUTELSKY,${ }^{2}$ SARA GOLDMAN, ${ }^{1}$ \\ EUGENE ROSENBERG ${ }^{1}$ AND DAVID L. GUTNICK ${ }^{1}$ \\ ${ }^{1}$ Department of Microbiology, George S. Wise Faculty of Life Sciences, Tel Aviv University, \\ Ramat Aviv, Israel \\ ${ }^{2}$ Department of Pathology, Sackler Medical School, Tel Aviv University, Ramat Aviv, Israel
}

(Received 30 March 1982; revised 20 September 1982)

\begin{abstract}
The immunochemical and immunocytochemical characteristics of three Acinetobacter calcoaceticus RAG strains were compared in order to clarify the relationship between antibodyinduced agglutination and the production of polyanionic extracellular emulsifier (termed emulsan). In addition to the parent, RAG-92, two mutant strains were examined: (1) a nonagglutinating emulsan-producer (AB15), and (2) an agglutinating mutant (16TLU) defective in the production of emulsan. A combined genetic-immunochemical approach was employed. This included the comparison of crossed immunoelectrophoresis patterns of parent and mutant supernates and the effect of absorption of anti-whole cell antiserum with mutant cells. In addition, agglutinability and competition studies were performed as well as electron microscopic cytochemistry. The results demonstrated that three major antigenic components were associated with the cell surface and the supernate. Mutant cells were altered both in their cell surface properties and in their extracellular products. One antigenic component, termed component $\mathrm{C} 3$, was the major cell surface agglutinogen; this component was absent in nonagglutinating mutants. Component C3 may be identical with or attached to the $300 \mathrm{~nm}$ projections on the parent cell surface, but it is not directly related to the presence of emulsan. It appears that emulsan plays little or no role in the phenomenon of antibody-induced agglutination of this organism.
\end{abstract}

\section{INTRODUCTION}

In a recent report (Bayer et al., 1981) we demonstrated that a surface-specific antiserum could be used to isolate nonagglutinating cell surface mutants of the petroleum-degrading bacterium Acinetobacter calcoaceticus RAG-1. The antiserum was raised against partially purified preparations of an extracellular polysaccharide emulsifying agent (termed emulsan), produced by this organism (Rosenberg et al., 1979; Zuckerberg et al., 1979). It was interesting that such nonagglutinating mutants were not affected in production of extracellular emulsan. Moreover, immunodiffusion patterns of cell-free supernates revealed but a single immunochemically identical antigenic component in both parent and mutant strains. Since emulsan is associated with the cell surface of the wild-type organism, extracellular emulsan production by nonagglutinating mutants could be explained either by (1) a failure of nonagglutinating mutants to accumulate emulsan at the cell surface, or (2) the presence both on the cell surface and in cell-free supernates of an additional antigenic component(s) which is missing in the nonagglutinating mutants.

In order to resolve this point, we have compared the patterns obtained from crossed immunoelectrophoresis (CIE) of supernates from the parent strain and two different mutants: one was a

† Present address: Biophysics Department, Weizmann Institute of Science, Rehovot, Israel. 
nonagglutinating emulsan producer and the other an agglutinating emulsan-defective strain. The resolution provided by CIE in conjunction with the use of an anti-whole cell antibody preparation (Bayer et al., 1980) enabled the detection of additional antigenic components released from the cell surface. Our evidence indicates that a relatively minor component, found in the cell-free supernates of agglutinating strains, represents the major cell surface agglutinogen, whereas the cell-bound form of emulsan contributes little to agglutination.

\section{METHODS}

Bacterial strains. Acinetobacter calcoaceticus RAG-92, a lysine-requiring auxotroph derived from the original RAG-1 isolate (ATCC 31012; Reisfeld et al., 1972) was the reference strain used for these studies. Two mutants derived from strain RAG-92 were also employed: AB15 was originally isolated by differential immunoprecipitation as a mutant which failed to agglutinate in the presence of antiserum (Bayer et al., 1981) and 16TLU was selected on the basis of colonial morphology following mutagenesis with diethylsulphate. Mutant 16TLU is defective in emulsan production and is closely related to those described previously (Pines \& Gutnick, 1981); colonies of $16 \mathrm{TLU}$ are visually less opaque than those of the parent strain. The mutants have remained stable for over two years.

Growth media and culture conditions. Cells were grown as previously described (Bayer et al., 1981) with gyratory shaking at 200 r.p.m. in liquid culture containing 0.15 M-potassium phosphate buffer, $\mathrm{pH} 7.0,0.8 \mathrm{mM}$-magnesium sulphate, $3 \mathrm{~mm}$-ammonium sulphate, $2.5 \%(\mathrm{v} / \mathrm{v})$ ethanol and $100 \mu \mathrm{g}$ lysine $\mathrm{ml}^{-1}$. Starter cultures were prepared by inoculating single colonies into $2 \mathrm{ml}$ of the above medium. Exponential phase cells were prepared by first inoculating fresh medium with a $1 \%(\mathrm{v} / \mathrm{v})$ inoculum from overnight starter cultures, and, following a $5 \mathrm{~h}$ growth period, introducing a $0.1 \%$ inoculum of the latter culture into a second flask containing fresh medium. The cells were harvested at a turbidity of 40 to 50 Klett units (measured in a Klett-Summerson colorimeter with a green filter). Stationary phase cells were generally harvested after $3 \mathrm{~d}$ growth (approximately $10^{3} \mathrm{Klett}$ units).

Preparation of cell-free supernates. Cell cultures, following $3 \mathrm{~d}$ growth, were centrifuged at $4{ }^{\circ} \mathrm{C}(8000 \mathrm{~g}$ for $10 \mathrm{~min}$ ) in a Sorvall RC2-B centrifuge. The supernates were collected, passed through a Millipore HAWP-45 filter and stored at $-18{ }^{\circ} \mathrm{C}$ in the presence of $0.005 \%$ sodium azide. Prior to use, the samples were centrifuged in an Eppendorf 5414 microfuge. Emulsan activity (determined by measuring the turbidity obtained by mixing supernates with a defined hydrocarbon solution) and viscosity measurements were performed as previously described (Rosenberg et al., 1979; Bayer et al., 1981).

Preparation of anti-whole cell (anti-RAG-92) antiserum. Rabbits were injected intravenously with $10^{9}$ washed, mid-exponential phase cells of $A$. calcoaceticus RAG-92. The rabbits were immunized on days 0,3 and 6 and bled on day 9. Thereafter, subsequent bleedings were performed $3 \mathrm{~d}$ after a booster injection consisting of the same RAG-92 cell preparation. A one month interval separated the primary and booster injections. The antisera were pooled. Double immunodiffusion was performed according to Ouchterlony (1958).

Absorption of antiserum with cells of $A B 15$. To remove from the antiserum those antibodies which were common in reacting with surface antigens of both RAG- 92 and AB15, the following procedure was used. An exponential phase culture of $\mathrm{AB} 15(200 \mathrm{ml})$ was washed with $0.15 \mathrm{M}-\mathrm{NaCl}$, and, following centrifugation at $8000 \mathrm{~g}$ for $10 \mathrm{~min}$, the cell pellet was resuspended in $2 \mathrm{ml}$ of the anti-whole cell antiserum. The cells and antiserum were incubated for $2 \mathrm{~h}$ at $4{ }^{\circ} \mathrm{C}$. After centrifugation at $8000 \mathrm{~g}$ for $10 \mathrm{~min}$, the supernate was subjected to a second absorption step with a second, washed exponential phase culture of AB15. In this manner, only the antibodies to antigens which were present on the parent strain (RAG-92) but absent from the mutant cell surface, should have remained in the absorbed antiserum preparation. Following absorption, the preparations were always tested against supernates from the homologous organism to ensure that no residual common antibody remained.

Agglutination assay. The desired strain was grown to exponential phase and cells were washed three times with $20 \mathrm{~mm}$-Tris buffer, $\mathrm{pH} 7 \cdot 1$, and resuspended in the same buffer to an $A_{400}^{1 \mathrm{~cm}}$ of approximately $1 \cdot 0$ to $1 \cdot 2$. A sample of washed cells $(0.6 \mathrm{ml})$ was added to a disposable 'half-micro' cuvette (C. A. Greiner, Nurtingen, West Germany) containing $0.1 \mathrm{ml}$ of an appropriate dilution of antiserum. The change in $A_{400}$ was measured at timed intervals in a Gilford Model 240 spectrophotometer. Preimmune serum was substituted for antiserum in control samples. The entire procedure was carried out at room temperature; sodium azide $(0.002 \%)$ was added to the buffer to prevent bacterial growth without interfering with the assay.

For comparative purposes, the time required for the reduction of cell turbidity to one-half its initial value (designated $t_{\frac{1}{2}}$ ) was a convenient measure of agglutinability for a constant dilution of antiserum. Since values for $t_{\frac{1}{2}}$ are inversely proportional to the extent of agglutination, the reciprocal of this measure, i.e. $\left(t_{1}\right)^{-1}$, was employed for graphic representation of agglutination.

CIE. CIE of cell-free supernates was performed according to a modification of the technique described by Weeke (1973). The stock electrophoresis buffer contained $2.06 \mathrm{~g}$ sodium barbital, $0.4 \mathrm{~g}$ barbituric acid and $0.1 \mathrm{~g}$ sodium azide per litre distilled water ( $\mathrm{pH} 8 \cdot 6$, ionic strength $0 \cdot 1$ ). The buffer was diluted $1 / 5$ in distilled water, both 
Table 1. Emulsan production by the three A. calcoaceticus strains used

$\begin{array}{lccc}\text { Strain } & \begin{array}{c}\text { Growth* } \\ \text { (Klett units) }\end{array} & \overbrace{(\text { units ml }}^{-1} \text { ) } & \eta_{\text {sp. }} \\ \text { RAG-92 } & 480 & 283 & 0 \cdot 26 \\ \text { AB15 } & 680 & 260 & 0 \cdot 22 \\ \text { 16TLU } & 510 & 31 & 0 \cdot 07\end{array}$

* Cells were harvested following a growth period of $72 \mathrm{~h}$.

$\dagger$ Emulsan yield is expressed both in terms of emulsan activity (units ml-1) and specific viscosity $\left(\eta_{\text {rel. }}-1\right.$ ) of the cell-free supernatant fluids. Values represent the average of duplicate samples derived from duplicate cultures.

for use as a running buffer and as a diluent for the $1 \%(\mathrm{w} / \mathrm{v})$ agarose (Pharmacia, agarose $\mathrm{A})$. Glass plates (Chance Brothers, Smethwick, U.K., $76 \times 51 \mathrm{~mm})$ were coated with agarose gels $(2 \mathrm{~mm}$ thick $)$. Samples $(7 \mu \mathrm{l})$ of the appropriate cell-free supernate (undiluted) were run in the first dimension at $25 \mathrm{~V} \mathrm{~cm}^{-1}$ for approximately $1.5 \mathrm{~h}$ (bromophenol blue was used as a marker). The second dimension gel contained $10 \mu$ undiluted antiserum (ml agarose $)^{-1}$ and was run at $8 \mathrm{~V} \mathrm{~cm}^{-1}$ for $20 \mathrm{~h}$.

Staining procedure. Electrophoresis gels were pressed to minimal thickness according to Laurell (1966), washed twice with saline and once in distilled water, dried and stained for $30 \mathrm{~min}$ in $0.02 \%(\mathrm{w} / \mathrm{v})$ Coomassie brilliant blue $\mathbf{R}$ (Sigma), dissolved in a solution of $7 \%(\mathrm{v} / \mathrm{v})$ acetic acid and $50 \%(\mathrm{v} / \mathrm{v})$ methanol. Plates were destained in a $50 \%$ methanol solution containing $7 \%$ acetic acid.

Cytochemical labelling procedure. Parent and mutant cells were labelled with cationized ferritin (Miles-Yeda, Rehovot, Israel) as previously described (Danon et al., 1972). About $10^{8}$ washed exponential phase cells were resuspended in $1 \mathrm{ml}$ Tris buffer. A solution of cationized ferritin $(0.5 \mathrm{mg}$ in $50 \mu \mathrm{l})$ was added and the suspension incubated at room temperature for $20 \mathrm{~min}$. The cells were centrifuged in an Eppendorf microfuge and the pellet was washed twice with Tris buffer. The cells were fixed with Karnovsky's fixative (Karnovsky, 1965).

Immunocytochemical labelling of the cell surface was carried out using the avidin-biotin complex according to our previously described procedures (Bayer et al., 1976a, 1979; Bayer \& Wilchek, 1980; Skutelsky \& Bayer, 1980). The absorbed antiserum was coupled with biotinyl- $N$-hydroxysuccinimide ester (Bayer \& Wilchek, 1974; Bayer et al., 1979) and the biotin-labelled antibody preparation was added to a suspension of RAG-92 cells $\left(10^{9} \mathrm{ml}^{-1}\right)$ in Tris buffer to a final protein concentration of $1 \mathrm{mg} \mathrm{ml}^{-1}$. The cells were allowed to stand for $10 \mathrm{~min}$ at room temperature and a further $50 \mathrm{~min}$ at $4{ }^{\circ} \mathrm{C}$. The settled cells were filtered, washed on a Millipore HAWP-45 filter and resuspended in a solution ( $1 \mathrm{mg}$ protein $\mathrm{ml}^{-1}$ ) containing ferritin-avidin conjugates (Bayer et al., $1976 \mathrm{~b}$ ). After incubation for $30 \mathrm{~min}$ at room temperature the cells were washed by centrifugation and fixed in Karnovsky's fixative.

Processing for electron microscopy. Cells were postfixed for $1 \mathrm{~h}$ at $4{ }^{\circ} \mathrm{C}$ in $1 \%(\mathrm{w} / \mathrm{v}) \mathrm{OsO}_{4}$, washed twice with distilled water and dehydrated in graded ethanol solutions. The dehydrated cells were embedded in Epon (Luft, 1961), and sections approximately $60 \mathrm{~nm}$ thick were obtained with an LKB-V microtome. The sections were mounted on naked 400 mesh copper grids and coated with carbon prior to viewing in a Jeol 100-B electron microscope at $80 \mathrm{kV}$.

\section{RESULTS}

Emulsification properties of parent and mutant strains. Emulsan activities of the parent and mutant strains are summarized in Table 1. Previous results had shown that the emulsan activity in the supernatant fluid, as well as the viscosity, was a function of the concentration of the emulsan polymer (Rosenberg et al., 1979). On the basis of the results in Table 1, therefore, $16 \mathrm{TLU}$ was classified as a strain defective in emulsan production, whereas strain AB15 displayed emulsan levels similar to those of the parent strain.

Agglutination of parent and mutant strains. To determine whether the production of extracellular emulsan was linked directly to the property of antibody-induced agglutination, the agglutinability of the parent strain (RAG-92) was compared with that of the emulsan-defective strain (16TLU). Introduction of the anti-RAG-92 antiserum (prepared against whole cells) to cell suspensions of either strain caused a marked agglutination of the cells. The times required for the reduction of cell turbidity to one-half its initial value $\left(t_{\frac{1}{2}}\right)$ were similar (Fig. 1), indicating 


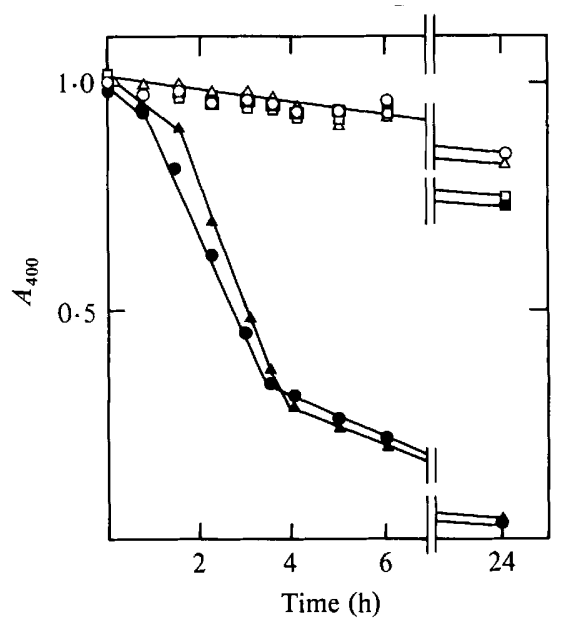

Fig. 1. Comparison of antiserum-induced agglutination between parent and mutant cells of $A$. calcoaceticus. Cells of the parent strain RAG-92 $(O, O)$, a nonagglutinating mutant, AB15 $(\square, \square)$, and an emulsan-defective mutant, 16TLU $(\triangle, \Lambda)$, were incubated either with normal rabbit serum (open symbols) or anti-whole cell antiserum raised against RAG-92 (filled symbols). In each case cells were grown to mid-exponential phase and were treated with a 1:500 final dilution of serum. In this and subsequent agglutination experiments, all values are the average of duplicate samples derived from duplicate cultures.

Table 2. Characteristics of emulsan-defective strains derived from A. calcoaceticus RAG-1 or $R A G-92$

\begin{tabular}{|c|c|c|c|c|}
\hline \multirow[b]{2}{*}{ Strain* } & \multirow[b]{2}{*}{$\begin{array}{c}\text { Growth† } \\
\text { (Klett units) }\end{array}$} & \multirow[b]{2}{*}{$\begin{array}{c}\text { Agglutinability }, \ddagger \\
t_{\frac{1}{2}}(\mathrm{~h})\end{array}$} & \multicolumn{2}{|c|}{ Emulsan yield } \\
\hline & & & (units $\mathrm{ml}^{-1}$ ) & $\eta_{\mathrm{sp}}$ \\
\hline AB6TLU & 480 & 4.0 & 14 & 0.07 \\
\hline 10 & 360 & 3.6 & 16 & 0.07 \\
\hline 301 & 410 & $4 \cdot 5$ & 30 & 0.04 \\
\hline 314 & 430 & $4 \cdot 7$ & 33 & $0 \cdot 11$ \\
\hline AG-1 & 620 & 3.5 & 39 & $0 \cdot 10$ \\
\hline
\end{tabular}

* Strain AB6TLU was derived from strain AB6 (Bayer et al., 1981) and selected on the basis of colonial morphology. The other emulsan-defective strains have been described previously (Pines \& Gutnick, 1981): strain 10 was selected by $R$. Avigad for poor growth on hexadecane as a carbon source, strains 301 and 314 were isolated by R. Avigad on the basis of phage ap3 resistance, and strain AG-1 was selected by A. Gottlieb for growth on low concentrations of ethanol as carbon source. All of these strains exhibit TLU colonial morphology.

$\dagger$ Cells were harvested following a growth period of $72 \mathrm{~h}$.

$\ddagger$ Agglutinability is expressed as the time necessary to reduce the turbidity of exponential cell suspensions (in the presence of antibody) to half of the original value. In all cases a 1:1000 dilution of antiserum was used.

that the kinetics of agglutinability and hence the interaction between the surface-specific antibodies and the cell surface agglutinogen(s) were similar for these strains (Bayer et al., 1981). In fact, several other emulsan-defective strains which were isolated by a variety of different methods (Pines \& Gutnick, 1981) all exhibited $t_{1}$ values which were equivalent to that of the parent strain (Table 2). In contrast, cells of $A B 15$ failed to agglutinate in the presence of antiRAG-92 anti-bodies (Fig. 1); this strain was thus classified as a nonagglutinating mutant as reported earlier (Bayer et al., 1981).

CIE of cell-free supernates. Using the antiserum prepared against cells of RAG-92, CIE of cellfree supernates derived from the parent strain revealed three major components, termed $\mathrm{C} 1, \mathrm{C} 2$ and $\mathrm{C} 3$ (Fig. 2a). Component $\mathrm{C} 1$ was identical to the single band observed previously by immunodiffusion (Bayer et al., 1981) and was the most prominent CIE peak. Component C2 consisted of a well-defined peak of relatively sparse precipitate morphology. Component $\mathrm{C} 3$ was 

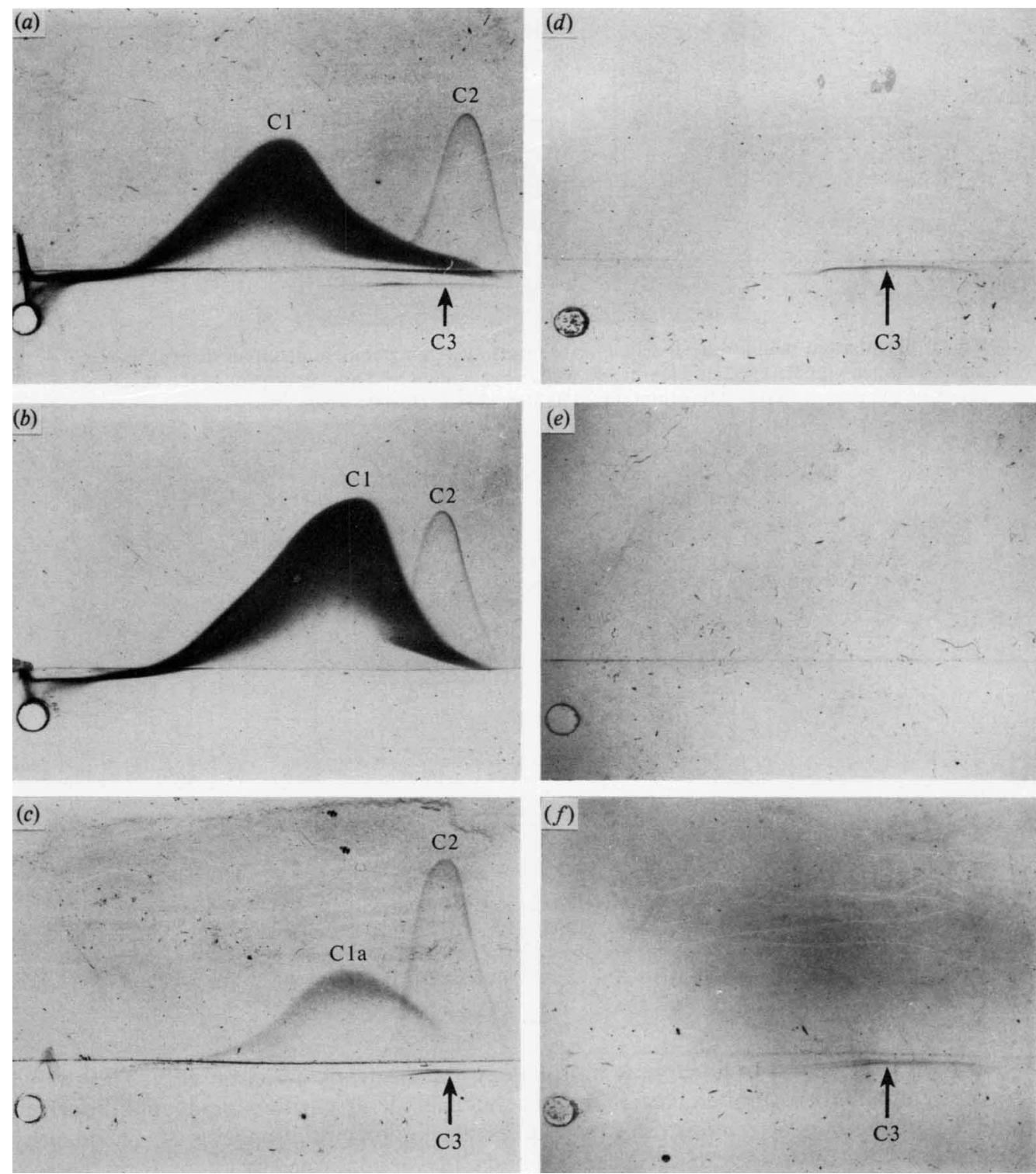

Fig. 2. CIE patterns of cell-free supernates derived from stationary phase cells of $(a)$ the parent strain RAG-92, (b) a nonagglutinating mutant AB15, and (c) an emulsan-defective mutant 16TLU, each against anti-RAG-92 cell antiserum. The CIE patterns of the latter strains against RAG-92 antiserum absorbed with $\mathrm{AB} 15$ cells are shown in $(d),(e)$ and $(f)$, respectively. The various bands or peaks are labelled as components $\mathrm{C} 1, \mathrm{Cla}, \mathrm{C} 2$ or $\mathrm{C} 3$. In each figure the anode is located at the right in the first dimension and at the top in the second. The results were typical of several experiments.

the least conspicuous of the three CIE components and appeared as a weak band which failed to penetrate the antiserum-containing gel.

The CIE pattern of $\mathrm{AB} 15$ (the nonagglutinating emulsan-producing strain) was similar to that of the parent in that components $\mathrm{C} 1$ and $\mathrm{C} 2$ were both present (Fig. 2b). Component $\mathrm{C} 3$, however, was consistently absent in the supernatant fluids derived from this mutant.

In the CIE pattern of the emulsan-defective mutant 16TLU (Fig. 2c), components $\mathrm{C} 2$ and $\mathrm{C} 3$ appeared similar to those displayed by the parent strain (Fig. $2 a$ ). However, component $\mathrm{C} 1$ was 


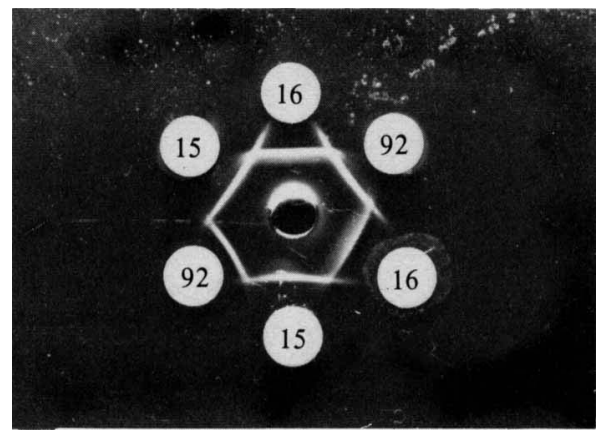

Fig. 3. Ouchterlony double diffusion analysis of supernates from parent and mutant strains. The centre well contained anti-RAG-92 antiserum and wells designated 92, 15 and 16 contained the supernatant fluids of the parent (RAG-92) or mutants AB15 or 16TLU, respectively.

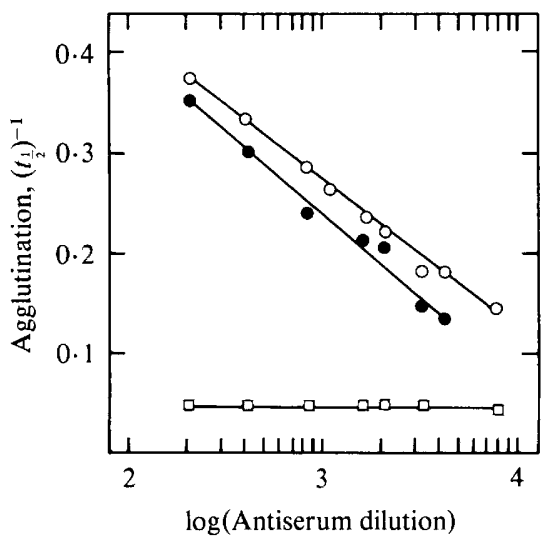

Fig. 4. Effect of antiserum concentration on the agglutination of parent (RAG-92) or mutant (AB15) cells. Cells of RAG-92 were incubated either with various concentrations of anti-RAG-92 cell antiserum $(\mathrm{O})$ or the same antiserum previously absorbed with AB15 cells $(O)$. Cells of AB15 were incubated with the unabsorbed anti-RAG-92 cell antiserum ( $\square$ ).

altered both with respect to precipitate morphology and electrophoretic mobility. The altered peak, designated $\mathrm{Cla}$, exhibited partial immunochemical identity with component $\mathrm{Cl}$ derived from the parent strain, as demonstrated by double diffusion precipitation (Fig. 3). The identity of the double diffusion lines with CIE peaks $\mathrm{C} 1$ and $\mathrm{Cla}$ was confirmed by tandem and crossedline immunoelectrophoresis (data not shown).

The anti-whole cell antiserum was absorbed exhaustively with washed cells of AB15 in order to eliminate cross-reacting antibodies. As a result, no CIE peaks were visible in the cell-free supernate of $\mathrm{AB} 15$ (Fig. 2e) indicating that the absorption process was effective. Using the same absorbed antiserum, the only component visible in cell-free supernatant fluids derived both from RAG-92 and 16TLU was C3 (Fig. $2 d, f$ ).

Agglutination using absorbed antiserum. The relationship of the antigens demonstrated by CIE, particularly $\mathrm{C} 3$, to the property of antiserum-induced agglutination of cells was studied by comparing agglutination levels of the parent strain with either absorbed or unabsorbed antiserum. Although cross-reacting antibodies against the major components (specific for CIE components $\mathrm{C} 1$ and $\mathrm{C} 2$ ) were removed from the antiserum upon absorption with cells of $\mathrm{AB} 15$, the absorbed antiserum preparation maintained similar levels of agglutination to those of the unabsorbed preparation. The agglutinability of both RAG-92 and AB15 was measured as a function of antiserum concentration (Fig. 4). Since $t_{\frac{1}{2}}$ is inversely related to agglutination, the 


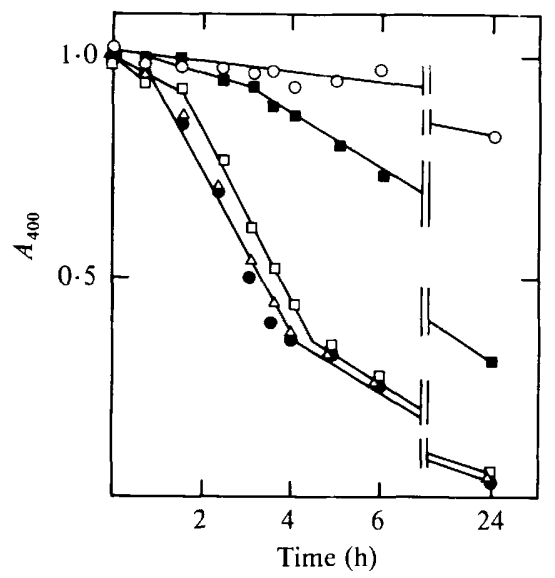

Fig. 5. Competitive effect of various additives on the normal agglutinating behaviour of the parent strain (RAG-92) with anti-RAG-92 antiserum. RAG-92 cells were incubated with rabbit preimmune serum $(O)$, anti-RAG-92 antiserum with no additives $(O)$, antiserum with AB15 (nonagglutinating) supernatant $(\square)$, antiserum with RAG-92 (parent) supernatant ( $\square$ ), and antiserum with purified emulsan $(\triangle)$. RAG-92 cells were harvested in mid-exponential phase. The antiserum was diluted to $1: 1000$ (final). A $2 \mathrm{mg}$ sample of purified emulsan or $200 \mu \mathrm{l}$ of the appropriate cell-free supernatant fluid were added to give a total volume of $700 \mu \mathrm{l}$ of agglutination mixture.

reciprocal value $\left(t_{\frac{1}{2}}\right)^{-1}$ was used to represent agglutinability. The extent of agglutination of the parent strain was exponentially related to the concentration of surface-specific antibodies. In contrast, no agglutination of $\mathrm{AB} 15$ cells was observed over the entire range of antibody concentration tested. Moreover, prior absorption of antiserum with cells of AB15 had relatively little effect on the capacity of the antibodies to agglutinate cells of RAG-92.

Inhibition of agglutination by various agents. In order to examine further whether component $\mathrm{C} 3$ was directly involved in agglutination, the effect of various cell-free preparations on the extent of antiserum-induced agglutination of RAG-92 cells was investigated (Fig. 5). Preincubation of antiserum with cell-free supernatant fluids from RAG-92 resulted in significant inhibition of antibody-induced agglutination. In contrast, neither purified emulsan nor AB15 supernatant (both of which lack component C3) significantly affected this property.

Ultrastructural aspects of parent and mutant strains. In order to determine the ultrastructural arrangement of the cell surface agglutinogen(s), two complementary labelling techniques were employed in this study. The first technique, which involved labelling bacterial cells with cationized ferritin, revealed extensive exocellular structures on both parent and mutant cells (Fig. 6), the most striking of which were the extended projections (about $300 \mathrm{~nm}$ in length) visible on cells of RAG-92 as well as 16TLU. These projections, however, were absent or perhaps altered on cells of $\mathrm{AB} 15$. The only projections observed on $\mathrm{AB} 15$ cells were considerably shorter in length (about $80 \mathrm{~nm}$ long). It should be noted that the cell surfaces of parent and both mutant types were heavily labelled with a layer of cationized ferritin particles immediately adjacent to the outer membrane.

The second technique involved labelling of the RAG-92 cell surface with a biotin-labelled absorbed antibody preparation, followed by the addition of ferritin-conjugated avidin. The distribution of ferritin particles in this case appeared as an accumulation of the label at discrete intervals radiating from the cell surface, generally at a distance ranging from 100 to $300 \mathrm{~nm}$ (Fig. 7). Unlike cells treated with cationized ferritin, extensive labelling of the outer membrane was not observed. The ferritin-avidin labelling pattern of strain 16TLU was equivalent to that of RAG-92, but no ferritin label was observed on mutant AB15 cells using this technique (data not shown). 

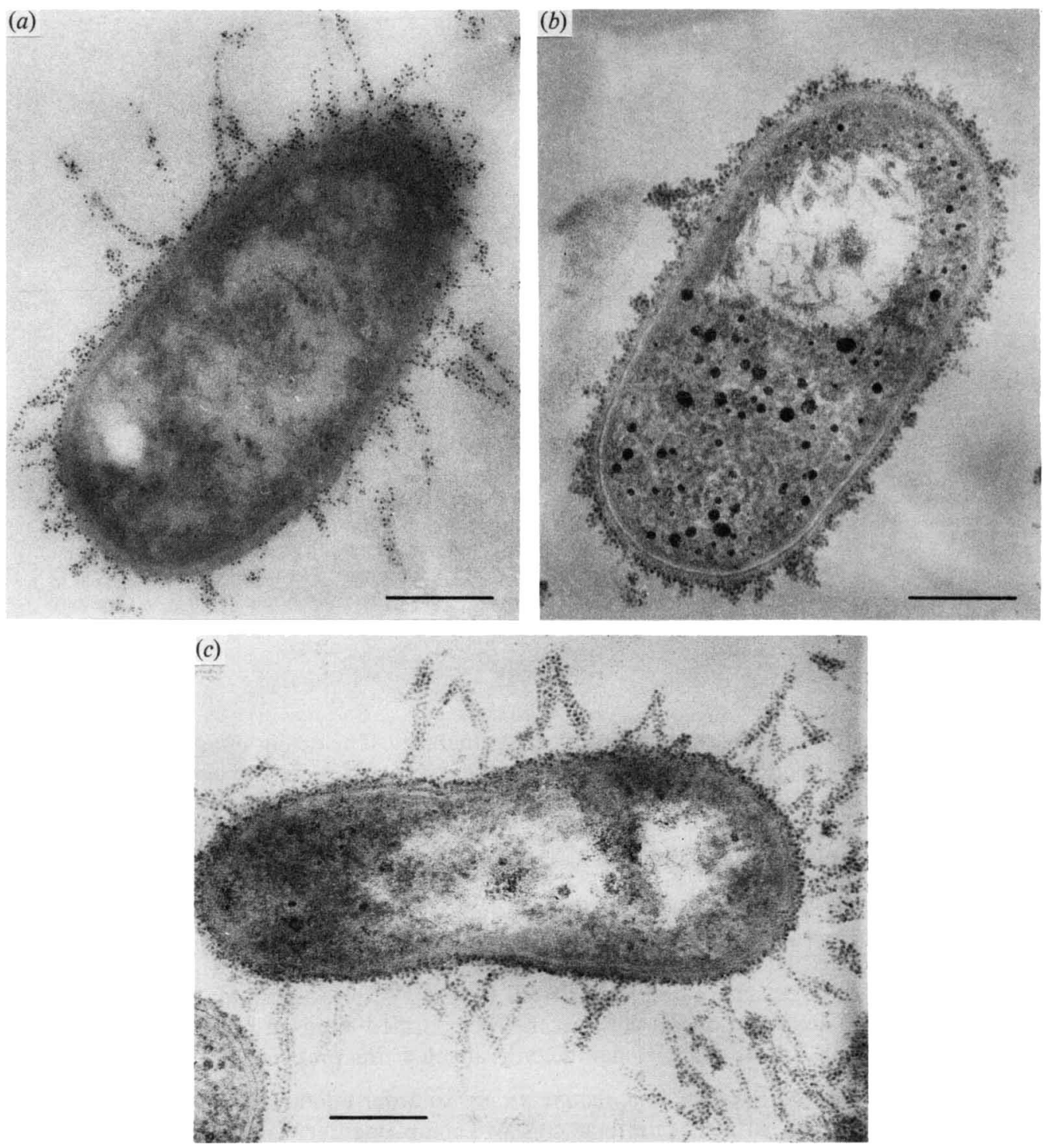

Fig. 6. Cell surface ultrastructure of $(a)$ RAG-92, (b) AB15 and (c) 16TLU, each labelled with cationized ferritin. Note the extended projections on the surface of RAG-92 and 16TLU and their absence on cells of AB15. The bar marker represents $250 \mathrm{~nm}$.

\section{DISCUSSION}

In order to study the potential relationship between the cell surface agglutinogen and extracellular emulsan in $A$. calcoaceticus RAG-1, the immunochemical and agglutinating properties of two mutant types (a nonagglutinating emulsan-producer and an agglutinating emulsandefective strain) were compared with those of the parent strain. A schematic representation illustrating the differences in cell surface characteristics of these strains is presented in Fig. 8.

In the case of the nonagglutinating emulsan-producer (AB15), only one of the three major CIE components was missing from the cell-free supernate. This was confirmed by antiserum absorption studies, which demonstrated that (1) components $\mathrm{Cl}$ and $\mathrm{C} 2$, derived from the cellfree supernate of $\mathrm{AB} 15$, are immunochemically similar to those of the parent strain, (2) the latter components originate from the cell surface since absorption with intact cells removes the 


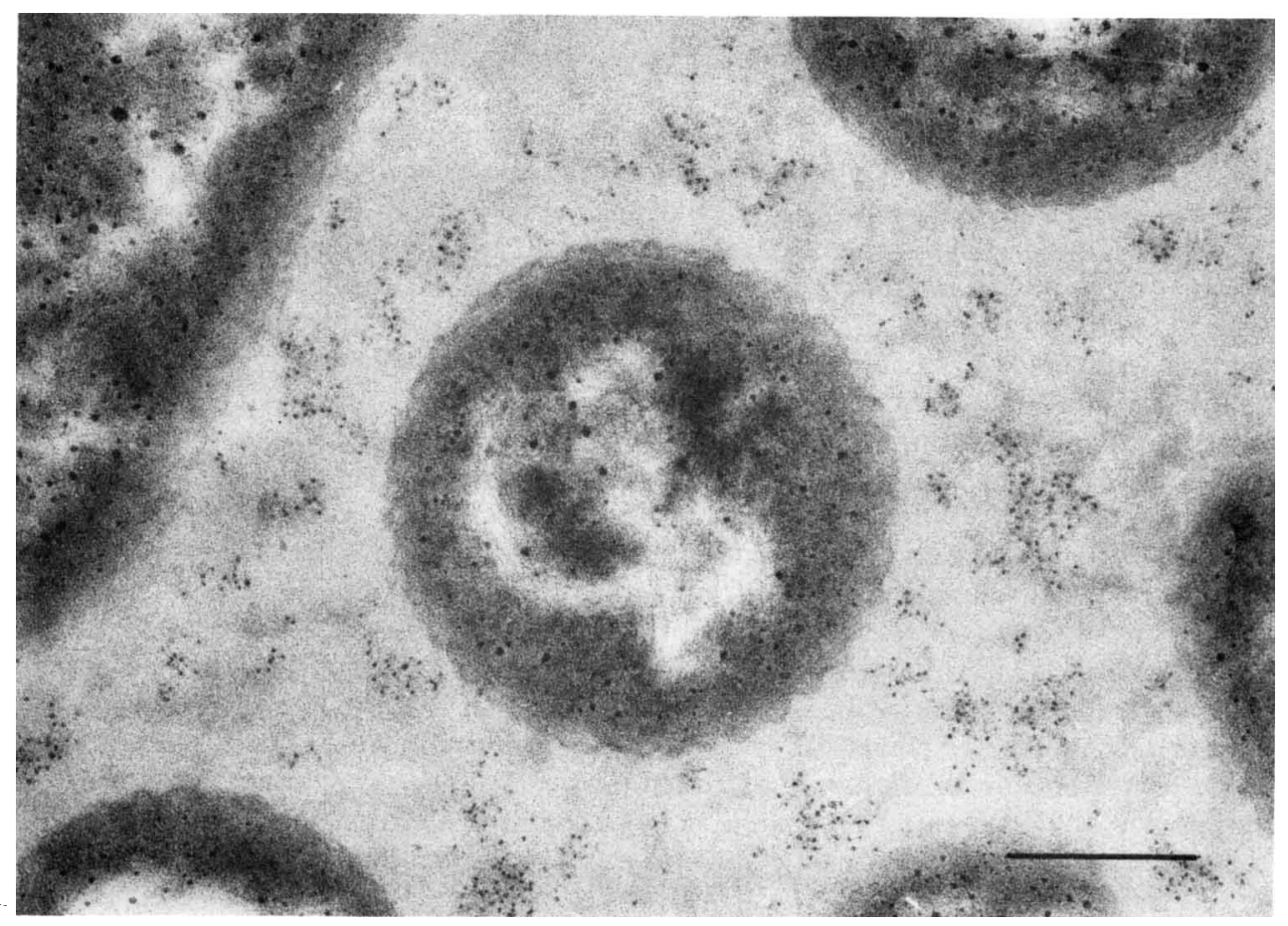

Fig. 7. RAG-92 cells treated with biotin-labelled AB15-absorbed antiserum, washed and then incubated with ferritin-avidin conjugates. Note the formation of ferritin clusters at discrete distances ranging from 100 to $300 \mathrm{~nm}$ from the outer membrane. The bar marker represents $250 \mathrm{~nm}$.

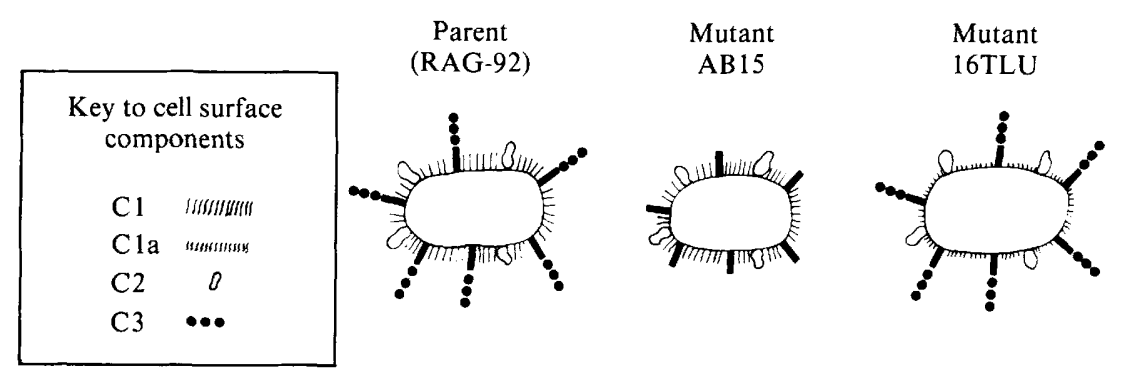

\section{Characteristic}

Emulsan

Agglutination

Component $\mathrm{C} 3$

$300 \mathrm{~nm}$ projections

Fig. 8. Schematic diagram summarizing the major characteristics and possible arrangement of cell surface components of the three $A$. calcoaceticus strains used in this study.

respective cross-reacting antibodies, and (3) $\mathrm{C} 3$ is indeed the sole component lacking from the $\mathrm{AB} 15$ supernate which could be detected by using the absorbed antibodies. In spite of the fact that absorption of anti-RAG-92 antiserum with AB 15 cells presumably removed the majority of cross-reacting antibodies, the effect on agglutination was negligible. This strongly suggests that component $\mathrm{C} 3$, or an immunochemically identical determinant, is directly involved in 
agglutination of RAG-92 cells. Further support was obtained by competition experiments which indicated that a given antigenic determinant present in the supernate of the parent strain (RAG92), but absent in that of the nonagglutinating mutant (AB15), was capable of inhibiting agglutination. Since the presence of component $\mathrm{C} 3$ is the only detectable antigenic difference between the parent and nonagglutinating mutant, this component apparently constitutes the major cell surface agglutinogen in this organism.

In the case of the agglutinating emulsan-defective mutant (16TLU), the correlation between agglutination and the presence of component $\mathrm{C} 3$ remains intact. Furthermore, large amounts of purified emulsan failed to inhibit antibody-induced agglutination of the parent strain, indicating that emulsan does not comprise a surface component which plays a role in the agglutination of $\boldsymbol{A}$. calcoaceticus RAG-92. Previous results demonstrating that nonagglutinating mutant strains retain the ability to produce extracellular emulsan (Bayer et al., 1981) can, therefore, be explained by the fact that the antiserum described in that study was raised against crude preparations of emulsan. The latter apparently contained additional antigen(s), including component $\mathrm{C} 3$. The resultant antiserum preparation was thus multispecific.

Additional evidence relating to the structural organization of this surface component was obtained by comparing the cell surface ultrastructure of parent and mutant strains. Treatment of cells with cationized ferritin provides a general method for the localization of anionic structures on the bacterial cell surface (Skutelsky et al., 1978; Weiss et al., 1979; Skutelsky \& Bayer, 1980). Using this technique, the major difference between agglutinating and nonagglutinating strains was the appearance in the former of extended projections measuring about $300 \mathrm{~nm}$ in length. The absence of these projections in the nonagglutinating strain suggests that these surface structures, either directly or indirectly, may play an important role in agglutination and may, in fact, either represent or serve as a carrier for the cell-bound equivalent of component $\mathrm{C} 3$. Further support in this regard is provided by the immunocytochemical labelling pattern of the parent (agglutinating) strain (Fig. 7), since the C3-specific antibodies appeared in discrete aggregates at distances from the outer membrane which approximated to those of the projections labelled by the cationized ferritin. The different labelling pattern between the immunocytochemical and the cationized ferritin techniques may reflect an intrinsic difference in the mechanics of the labelling method itself. The use of the biotin-avidin complex as an intermediary (sandwich) between the antibody and the electron-dense marker could account for the aggregated labelling pattern in this case which may have contributed an additional source of spatial error and consequent loss in resolution. It is interesting to note that the cells shown in Fig. 7 had been agglutinated by the antibody preparation; the location of the ferritin marker thus represents sites of agglutination between cells, and consequently the position of the cell surface agglutinogen.

Finally, the strategy described in this report, together with that of our previous study (Bayer $e t$ al., 1981) constitutes a general approach which should prove applicable in many cases where little is known at the molecular level regarding the structure-function relationship of a hypothetical surface component (though in the case of $A$. calcoaceticus the analysis was made easier due to the relatively simple antigenic structure of the cell surface). Using a combined geneticimmunochemical approach, we were able to design a sensitive qualitative (easily rendered quantitative) identification procedure applicable for immunochemical and immunocytochemical evaluation of the desired surface component.

The embedding, sectioning and technical skills of Mr Yaakov Delareia are gratefully appreciated. Mr Felix Skandarani was responsible for additional electron microscopic services. The excellent photographic work was the effort of Miss Lita Maman. The authors would also like to thank Drs Itzhak Ofek and Rafi Lamed for critical reading of the manuscript. E. A. B, is the recipient of an NIH Public Health Service Award no. F32-ES5210.

\section{REFERENCES}

BAYER, E. \& WILCHEK, M. (1974). Insolubilized biotin for the purification of avidin. Methods in Enzymology 34, 265-267.
BAyer, E. A. \& WilcheK, M. (1980). The use of the avidin-biotin complex in molecular biology. Methods of Biochemical Analysis 26, 1-45. 
Bayer, E. A., WilcheK, M. \& Skutelsky, E. (1976a). Affinity cytochemistry: the localization of lectin and antibody receptors on erythrocytes via the avidinbiotin complex. FEBS Letters 68, 240-244.

Bayer, E. A., Skutelsky, E., WynNe, D. \& WilcheK, M. $(1976 b)$. The preparation of ferritin-avidin conjugates by reductive alkylation for the use of electron microscopic cytochemistry. Journal of Histochemistry and Cytochemistry 24, 933-939.

BAyeR, E. A., Skutelsky, E. \& WilcheK, M. (1979). The avidin-biotin complex in affinity cytochemistry. Methods in Enzymology 62, 308-315.

Bayer, E. A., Rosenberg, E., Goldman, S. \& GUTNICK, D. L. (1980). Immunological characterization of cell surface mutants of a petroleumdegrading bacterium. Abstracts, 13th FEBS Meeting, Jerusalem, p. 25.

Bayer, E. A., Rosenberg, E. \& Gutnick, D. (1981). The isolation of cell surface mutants of Acinetobacter calcoaceticus RAG-1. Journal of General Microbiology 127, 295-300.

Danon, D., Goldstern, L., Marikovsky, Y. \& SKUTELSKY, E. (1972). Use of cationized ferritin as a label of negative charges on cell surfaces. Journal of Ultrastructure Research 38, 500-510.

KARNovsKY, M. J. (1965). A formaldehyde-glutaraldehyde fixative of high osmolality for use in electron microscopy. Journal of Cell Biology 27, 137-138.

LAURELL, C. B. (1966). Quantitative estimation of proteins by electrophoresis in agarose gel containing antibodies. Analytical Biochemistry 15, 45-52.

LuFT, J. H. (1961). Improvements in epoxy resin embedding methods. Journal of Biophysical and Biochemical Cytology 9, 409-414.

OUCHTERLONy, O. (1958). Diffusion-in-gel methods for immunological analysis. Progress in Allergy 5, 1-78.
Pines, O. \& Gutnick, D. L. (1981). Relationship between phage resistance and emulsan production, interaction of phages with cell-surface of Acinetobacter calcoaceticus RAG-1. Archives of Microbiology 130, 129-133.

Reisfeld, A., Rosenberg, E. \& Gutnick, D. L. (1972). Microbial degradation of crude oil: factors affecting the dispersion in seawater by mixed and pure cultures. Applied Microbiology 24, 363-368.

ROSENBERG, E., ZUCKerberG, A., RUBINOWITZ, H. \& GUTNICK, D. L. (1979). Emulsifier of Arthrobacter RAG-1: isolation and emulsifying properties. $A p$ plied and Environmental Microbiology 37, 402-408.

SKUTELSKY, E. \& BAYER, E. A. (1980). Induced affinity in cell surface cytochemistry. In Electron Microscopy 1980, 7th European Congress of the E.M. Foundation, vol. 2, pp. 272-278. Edited by P. Brederoo \& W. de Priester.

Skutelsky, E., Hoglund, S., Morein, B. \& Bayer, E. A. (1978). On the ultrastructural localization of cell surface sialyl residues versus anionic sites. In Electron Microscopy 1978, vol. 2, pp. 294-295. Edited by J. M. Sturgess. Ontario: Imperial Press.

WEEKE, B. (1973). Crossed immunoelectrophoresis. Scandinavian Journal of Immunology 2, suppl. 1, 4756.

Weiss, R., Schiefer, H. G. \& Krauss, H. (1979). Ultrastructural visualization of Klebsiella capsules by polycationic ferritin. FEMS Microbiology Letters 6, 435-437.

Zuckerberg, A., Diver, A., Peeri, Z., Gutnick, D. L. \& Rosenberg, E. (1979). Emulsifier of Arthrobacter RAG-1: chemical and physical properties. Applied and Environmental Microbiology 37, 414-420. 